\title{
The automation of teaching processes based on knowledge processing
}

\author{
Stefan Svetsky, Oliver Moravcik \\ Faculty of Materials Sciences and Technology, Slovak University of Technology in Bratislava, Slovak \\ Republic; \\ stefan.svetsky@stuba.sk; oliver.moravcik@stuba.sk
}

\begin{abstract}
Technology-enhanced learning as one of the EU research priorities is focused on "how information and communication technologies can be used to support learning and teaching". However, such "definition" is too much general, so, mostly technology-driven approaches are prevailing in the practice, which do not take enough in consideration didactic aspects of knowledge processing, and that teaching processes are related to mental processes of individuals. In addition, there are many open questions, especially "what is knowledge", "what is knowledge representation". An interdisciplinary definition of knowledge is missing, despite the fact that teaching processes are knowledge based. Within a long-term participatory action research on TEL when teaching bachelors, a strategy of automation of teaching processes was evolved. This seem to be a crucial point for solving any personalized computer support of teacher and students. Because these processes are primarily uncertain, or unstructured, it was found, that to make these processes better computerizable, a unification both teaching and informatics processes is needed. In this context, the knowledge processing is based on an idea of "virtual knowledge unit" (as a part of patent application, 2014). For this purpose, an in-house software has been developed that enables individuals to perform a "batch knowledge processing paradigm" in order to process a large amount of knowledge in natural language on their personal computers, university's cloud and servers. This paper deals with a specific approach to automation of teaching processes based on the knowledge processing.

Keywords: Technology enhanced learning, Knowledge, Knowledge processing, Automation of teaching processes, Database technology.
\end{abstract}

\section{Introduction}

Research on Technology-enhanced Learning (TEL) belonged to the priorities under the European Union's Seventh Framework Programme (FP7). According to European research, TEL investigates "how information and communication technologies can be used to support learning, teaching, and the development of competence throughout one's life" [1]. For example, the latest calls was focused on Educational Data Mining and Learning Analytics issues.

A participatory action research on TEL (PAR) was at the beginning mostly empirical. It was based on a simply idea to support by computer whatever is needed in classrooms when teaching bachelors students. The PAR focus was especially on personalized support of teacher as a key player within teaching processes, and step by step was transformed on systematic research on TEL. This research can be characterized by 
the developing phases: (i) e-Learning), (ii) technology - driven approach, (iii) educational (didactic) driven approach, and (iv) the well balanced combined technology - educational driven approach (more details can be found in [2-5]. During this period the faculty participated as well on research EU FP7 project proposals KEPLER (2007, focus was on system of keywords and ontology linking WEB-libraries with teaching processes), L3Pulse (2013, focus was on how to link knowledge flow within teaching processes to learning analytics). Actually, within PanEULangNet proposal for the first Horizon 2020 call ICT 17 (the cracking language barriers) the focus was on "embedding a human factor into automated machine translation system".

To better understand this paper, it should be mentioned that when comparing the mentioned empirical research approach to personalized computer support with existing approaches, these key problems were found:

- such research approach is considered on American and European universities as "participatory action research", i.e. when a teacher explores technology for his own targets and teaching activities [6], however, moreover, in our case the researcher design his own technology (he writes programming codes for database applications)

- reviewers, evaluators or opponents consider the developed "batch information and knowledge paradigm" (as a TEL's method), the in-house software *BIKE /WPad (as TEL's tool), and created TEL-system for a complex issue of several areas of Computer Science (e.g., knowledge management, soft computing, natural language processing, human computer interaction, text mining,...) - so, the BIKE seems to be an all-in-one software (something like an "empty knowledge based system")

- BIKE - Batch Information and Knowledge Editor/Environment; WPad-Writing Pad

- The research approach is different from state-of-the-art in the view of the abstraction of knowledge, knowledge representation, and knowledge processing in connection to support mental processes of teacher (individuals) within teaching processes. This resulted in formulation of a virtual knowledge unit which could be understandable both by humans and computers without a need to design machine readable schemas and use knowledge representation languages (e.g. RDFs, OWL). This idea is a part of application submitted on Slovak Patent Office (4/2014).

In this context, the actual PAR on TEL is understood as the "automation of knowledge based processes ", i.e. it considers teaching for teaching and learning processes, and the knowledge should be processed as a parameter of the teaching process. In addition, this approach, must challenge not only to issues as how to solve didactics aspects but how to structure domain content, teaching processes and subprocesses as well, in order to make these processes better computerizable (despite the fact that these are not enough described, structured, or standardized). One should be always aware that any education system is based on transition and transfer of domain knowledge into the brain of students, thus, within teaching processes, and directed by a teacher. Moreover, in comparison with automation of dead technical systems, there is no guaranty whether student (individuals) will have understood a content of curriculum properly (although the automation "works"). Due to this complexity of automation, and support of cognitive processes respectively, the PAR research challenges to many terminological problems both from educational (see any didactic text book, e.g. $[7,8]$ ) or informatics point of view (it does not exist tailored Computer Science discipline). 
Stefan Svetsky \& Oliver Moravcik; The automation of teaching processes based on knowledge processing, Transactions on Machine Learning and Artificial Intelligence, Volume 2 No 5 Oct (2014); pp: 52-63

\section{Terminological Challenges of Research on Tel}

The global or institutional challenges regarding a role of digital technology in supporting teaching processes are comprehensively described in [9]. The more detailed information on TEL as a research field can be found in in [1] (EU ICT research policy), in $[6,10]$ specific books, research reports of networks of excellences [11,12], as well in the published papers of authors of this paper [2-5], in which another appropriated literature is recommended (e.g. [13-16]. In this literature or in the contemporary scientific literature, it is often criticized that technology - driven approach dominates too much in state-of-the-art, which does not take enough in consideration didactic aspects of knowledge processing, and that teaching processes are related to mental processes of individuals (teachers, students, researchers), or knowledge workers in general. This results in fact that TEL research outcomes into educational practice are often considered for questionable.

For example, in [17] the TPACK framework (Technology, Pedagogy and Content Knowledge) is recommended as "a useful tool for the consideration of the interaction of technology with content and with pedagogy". This model should be helpful in overcoming "perceived barriers to the effective integration of ICT in teaching and learning environments".

In [18] a more education specific technological approach is required, because (i) "HE TEL/IT community has been just ineffective at delivering real improvements in education - some of the key reasons for this failure are embedded in the terminology itself", (ii) "people are transfixed by generic, off-the-shelf technology, developed by other people for other purposes -and the importance (even the possibility) of education-specific technology is ignored", and (iii) "... European Commission, which has funded a series of large academic research projects into TEL, explicitly recognized that there was a general "absence of evidence" that the projects had achieved lasting impact". The conclusion is: "TEL is a poorly conceived acronym, a new approach is needed that focuses on 'education-specific technologies', and we should leave 'TEL' behind and talk instead about 'education technology'.

The complexity of approaches to computer support of teaching can be also explained on another example from the University of Oxford. The course eLearning was recently renamed to Learning and Technology with this justification: "More recently, terms such as Technology Enhanced Learning and Educational Technologies have been popular, but the first is somewhat loaded in meaning, and the second too technology-focused" [19].

If one is a teacher, researcher - beginner, even expert, he may be confused about this existing terminological chaos in scientific literature. Moreover, this concerns surprisingly as well the term "knowledge", despite the fact that teaching, or related cognitive and mental processes of humans are knowledge based. Thus, although the "knowledge" is an important interdisciplinary issue, and frequently used term, it has different meaning in different research fields. This has an negative impact on the practice because experts of fields as are education, knowledge management, psychology, philosophy, artificial intelligence, Semantic WEB, including teachers and students do not understand each other.

One could continue by discussing another terminological issues related to the data, information, knowledge, big data, linked data, and so on. However, this paper is not focused on the analyzing of complexity of terminology. This, was mentioned mainly due to a better understanding that any automation of teaching processes, which is based on the knowledge processing, requires researchers to 
model an interdisciplinary acceptable abstraction of knowledge, or knowledge representation for the purpose of personalized computer support. If any practical abstraction was at the disposal - thus, the virtual knowledge unit in our case, it would enable to solve issues "how to support", respectively "how to solve programmatically" the infinity of knowledge flow within the infinity of teaching processes and sequences of sub-processes that are daily performed by teachers (including any knowledge workers).

In this context, there is a certain analogy between the presented personalized automation based on knowledge processing (the focus is on building tools for helping teachers in their work rather than replacing them) and a vision of Nielsson's "habile systems" within the field of Artificial Intelligence (he argues: "achieving real human-level artificial intelligence would necessarily imply that most of the tasks that humans perform for pay could be automated") [20].

\section{The Methodology of Automation of Teaching Process}

Teachers, students, or humans in general, all need to work with knowledge in their natural language. This requires humans and computers to be able read the same texts. In this view, the PAR on TEL resulted in the interdisciplinary acceptable formulation of knowledge and knowledge representation (the mentioned universal virtual knowledge unit), the developing in-house all-in-one software BIKE / WPad, and in implementation of a novel paradigm of batch knowledge processing, which enables teacher, or individuals to work out a large amount of information and knowledge, including the building up of supporting virtual space and the overall TEL system (the principles are described in [3] ). This research can be characterized by the following issues and categories.

\subsection{TEL tools}

"all-in-one" database applications BIKE/WritingPad, BIKE 2/WPad, virtual learning environment /virtual learning space on university's servers, communication channels (internet php/mysql-application), virtual application of technical calculations (for courses of study "Chemistry", and "Background of environmental protection" -this is a php-solution generated by the BIKE), including various tutorials and tests.

Note: all-in-one means, that it works both as desktop, and internet application, and covers tens of areas of computer science.

\subsection{Databases platforms and languages}

FoxPro for Windows 2.6a, Visual FoxPro 9, MySQL, DB2 (IBM); foxpro, html, C++, php, SQL.

\subsection{Research outcomes}

Applications into teaching bachelors: a bulk-design of teaching and slf-study materials; writing semester works; embedding teaching curriculum into communication channels for several courses of study; modelling of calculations, teaching tutorials and tests for PAR purposes; multi-language support ; testing of audio technologies (TTS, Speech Recognition); personalized support of individual teachers; modelling of multi-medial support (resulted in a anti-plagiarism methodology); modelling of feedback and communication; modelling of methodology of teaching programming languages (a cooperation between WPad and source forge C++ application ( http://www.bloodshed.net/dev/devcpp.html).

\subsection{Computer Science and IT research areas (projects topic)}

these are mentioned without a strictly classification: database technologies, programming languages, knowledge processing, knowledge repositories, knowledge management system, combined data-/ text-/ 
Stefan Svetsky \& Oliver Moravcik; The automation of teaching processes based on knowledge processing, Transactions on Machine Learning and Artificial Intelligence, Volume 2 No 5 Oct (2014); pp: 52-63

WEB-mining, virtual learning environments,, learning analytics, soft computing; technology enhanced learning, blended learning, active learning, cooperative learning, e-learning. For example the BIKE 2 consist of around two thousands programming codes and hundreds of items of user menu (in other words the programming code was written in the way that they cover useful functions or elements of the above mentioned research areas. Therefore, it works as the personalized all-in-one software).

\subsection{Methodology pillars}

- The modelling unification of content, teaching processes, and didactic approaches (communication for a feedback teacher-students) to be computerizable.

- The modelling automation of informatics processes, which are performed by teachers and students on desktop computers, faculty's cloud and servers.

- The design of set of applications, which integrate these modelled humans and computer activities, and enhance teaching processes in classrooms, including self-study.

- The strategic approach that the computer support of teaching processes is basically the automation of these processes based on knowledge (flow) processing, which is controlled by the teacher, and performed in the natural language.

- The teacher (to be sustainable) needs the complex supporting system that enlarged his social memory, and skills related to his mental (cognitive) processes, thus, the computer works as teacher's partner, "mind-ware", or "external virtual chip".

This approach illustrated schematically the Figure 1.

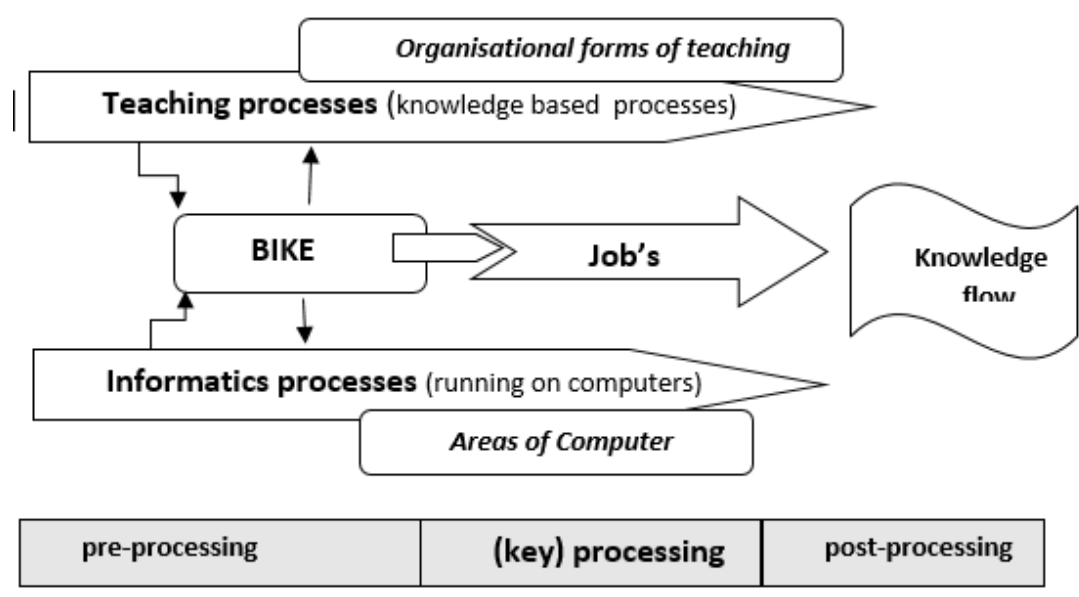

Figure 1: Schema of automation of teaching processes (knowledge flow processing)

\section{The examples of Applications in Teaching Bachelors}

To model the content and processes, the writing semester works resulted to be ideal. For this purpose, the BIKE (WPad) cooperates with the browser OPERA (version 9.27), which has two browser-specific features "Notes" and "Sessions". These enabled students (individuals) (i) to open many windows in one step including scrolling between them, (ii) to mark with mouse a text on the computer screen, and save it as the Notes (*.adr file), (iii) to save many open windows with the surfed internet pages into the 
Session (*.win file). The functions Notes and Sessions work as retrieving tools "for dummies", i.e. enabled students - also with very low informatics skills, to create and catalog own libraries consisting of the visited WEB-pages, and teacher to collect the *.adr and * win files from computers in the classroom into one cooperative study material, including possibility sending these files via e-mail.

This was used for training of multilingual retrievals when writing semester works (a simulation of working with literature), because the WPad (installed on computers in the classrooms) has in the user menu item for batch internet retrieving. This means, that students clicked on the item and simply wrote some keywords within WPad (or via using F5-key). After some seconds OPERA opened a sat of windows with search results, which were made up by Google, Bing, Yahoo and IxQuick search engines. Activities are commented on communication channels (php/mysql application), which can be used for teacher's instructions, information exchange or also for uploading/downloading files to/from the faculty's server. These activities illustrate Figures 2-4.

\begin{tabular}{|l|}
\hline Photosynthesis tutorials \\
Photosynthesis dark phase \\
Photosynthesis light phase \\
Krebs cycle
\end{tabular}

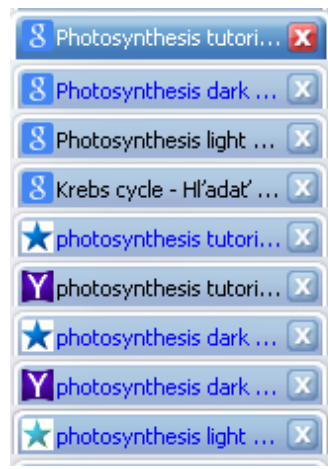

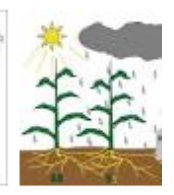

Overview of Photosynthesis Tutorial Ww.sophia.org/overview-of-photosynth We explain Overview of Photosynthesis with vir Ways(TM) approach from multiple teachers. Thi:

Tutorial 8.2 Photophosphorylation - WH

Figure 2: Screenshots of the batch internet retrieving (left: keywords, right: search engine results into OPERA)

\begin{tabular}{|c|c|}
\hline $\begin{array}{l}\text { OBSAH: [1] [Nahrávanie súborov z } \\
\text { počitača - upload] } \\
\text { SVET } \\
\text { ALL } \\
\text { UPLOAD } \\
201405-11 \text { PJ2014 }\end{array}$ & $\begin{array}{l}\text { - [Nahrajte váš súbor - upload] do PJ } \\
\text { - [Kontrola] - adresár (alebo kliknite na číslo záznamu) }\end{array}$ \\
\hline $\begin{array}{l}\text { OBSAH: [2] [Virtuálny priestor so } \\
\text { študijnými materiálni ] } \\
\text { SVAT } \\
\text { ALL }\end{array}$ & $\begin{array}{l}\text { Adresár IMGS so vzorovými programami } \\
\text { - [2014] - vložené študentami } \\
\text { - [2014] - vložené súbory - aktuálny adresár } \\
\text { - [MMGS] - študijné materiály ... }\end{array}$ \\
\hline
\end{tabular}

Figure 3: Screenshot of the communication channel with teacher's instructions and information exchange (e.g. after clicking on the [2014]), students see the study materials, which they constructed via the shared internet retrieving)

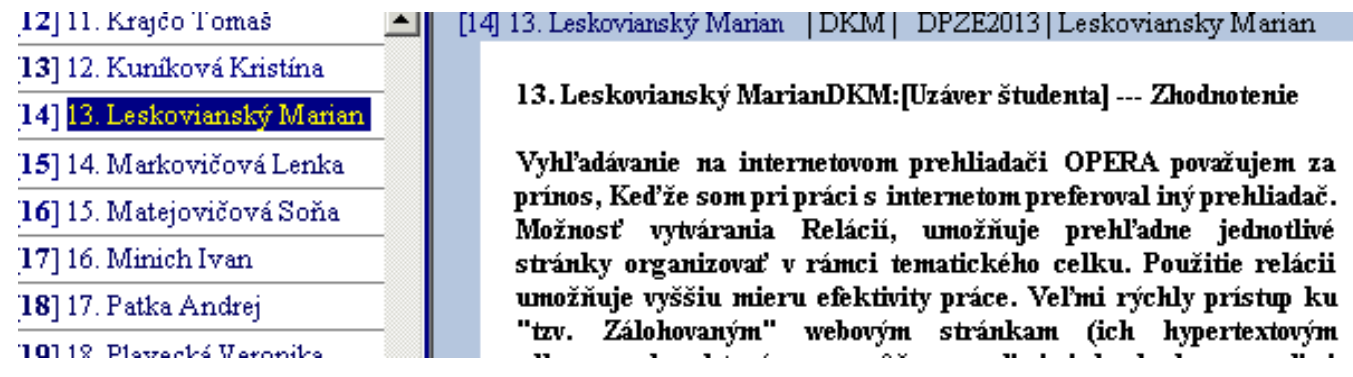

Figure 4: Screenshot of html-file with collected opinions of students related to effectiveness of OPERA 
Stefan Svetsky \& Oliver Moravcik; The automation of teaching processes based on knowledge processing, Transactions on Machine Learning and Artificial Intelligence, Volume 2 No 5 Oct (2014); pp: 52-63

Figure 5 illustrates a schema of modelling learning analytics issues in the classroom with computers. There were indicated and analyzed: (i) log-files from internet domain, (ii) communication channels (faculty's server), (iii) off-line desktop computers (records in WPad, and evidence files). This process enable teacher to model an interlinking of learning analytics directly with the curriculum and tacit knowledge of students because WPad-tables consist of a set of linked virtual knowledge units.

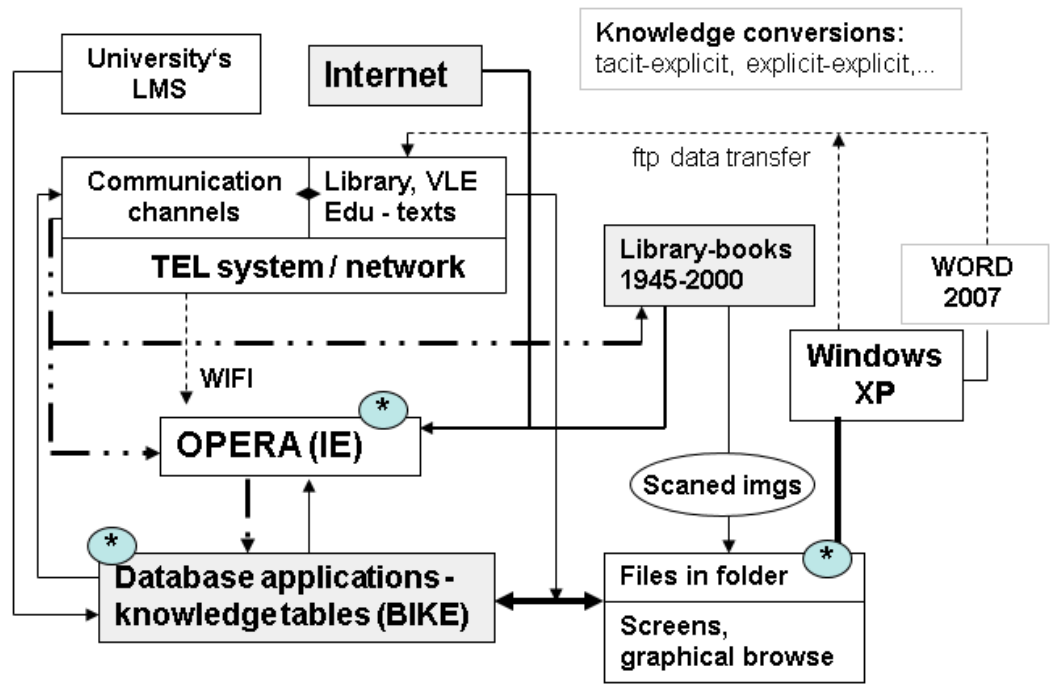

Figure 5: Schema of modelling learning analytics in the classroom - interlinking process knowledge with data

\section{The examples of teacher's activities support}

The computer support of teacher's activities consist of two levels

- The automation of common activities within the teaching process - this means, that the teacher selects appropriated items from the user menu of BIKE/WPad, performs batch knowledge processing paradigm, and utilizes the TEL system with libraries, study materials, tutorials, informatics tools.

- For sophisticated applications - this requires (i) modelling teaching processes, (ii) modelling informatics processes, and (iii) writing programming codes for database applications.

The modelling teaching processes basically means, that any teaching process must be analyzed for sequences of processes steps (to be more certain, structured, and computerizable).

The modelling informatics processes means, that teacher's activities running on the computer must be also investigated in the view of repeatability of steps and a need to solve adaptability of BIKE/WPad with Windows, browsers or existing software and hardware. This is a basis for writing sequences of programming codes, something like triggers when using relational databases.

The writing programming codes for database applications represents the core of automation of teaching processes. Because if the teacher defines steps of any teacher process, i.e. his structure and has at his disposal a portfolio of programming tools, then he can start with semi-automatic and automatic activities, writing a set programming codes and testing within teaching. Maybe one of the most important issue is to divide activities on default activities an optional activities. Just here is the added value of human factor, i.e. the synergic effect of personalized computer support is achieved by the cooperation between teacher 
and computer, and this is based on the fact that teacher knows preferably what he needs to solve within his teaching, how often, at what time, to what extent, how fast, how often, etc. If the computer support was based on dominancy of machine - driven approach (a standard approach for Artificial Intelligence), these priorities does not know to formulate any machine. In addition, in the state of the art specific machine readable schemas and tailored languages are prevailing for knowledge processing. As was mentioned above, the needed effect is achieved in our case by natural language and that the knowledge abstraction enable both humans and machines to read the knowledge. Thus, then the knowledge can be processed within the teaching process through a synergic interoperability between teacher and computer in automatic or semi-automatic way. However, the more detailed description is beyond this paper, and it is still a question of the next progress because the PAR on TEL is based on implementing applications in the practice firstly. The next step is a back-analyze, "way it works", or "what fields of Computer Sciences cover the solution", or "what type of organizational form of learning is solved up".

Figures 6-7 illustrate the automation of common teacher's activities.

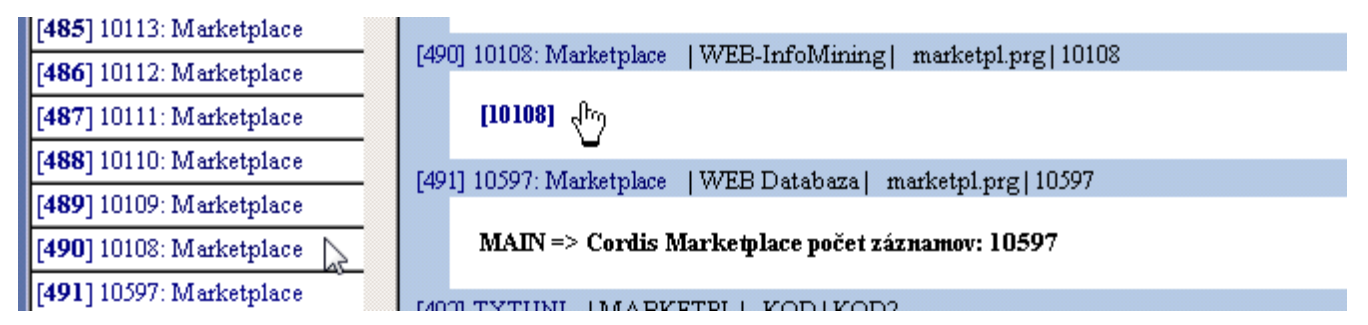

Figure 6: Screenshot of solving bilingual navigation via WEB-mining from the European database Marketplace

\begin{tabular}{|c|c|}
\hline 2 Vyvoj modelov pre ... $x$ & \multirow{3}{*}{$\begin{array}{l}\text { [Down }]<=[11] \Rightarrow \text { Koncept HCS modelu 3E vs. koncept Corporate Social Resposihility (CSR) } \\
\text { Materiálovotechnologická fakulta STU v Bratislave } \mid 73286.00\end{array}$} \\
\hline 3 3 Ývoj bezolovnatej... $X$ & \\
\hline 4 Výskum zvárania a ... X & \\
\hline 5 Vyskum uplatnenia ... X & [Table:] $\Rightarrow$ APVV \\
\hline ¿ 6 Veda bližsie kštude... $X$ & [TXTUNI:] LPP-0384-09 \\
\hline 7 Riešenie technológi... X & [kodf:] Koncept HCS modelu 3E vs. koncept Corporate Social Resposibility (CSR \\
\hline
\end{tabular}

Figure 7: Screenshot of final output from national database of founded projects (the aim was to found data and how many faculty's projects were founded during previous years from thousands of accepted projects)

Figures 8-11 illustrate solving the more sophisticated applications - the modelling creation of personal bilingual corpora, as a set of screenshot captured within working out of the European Parliament Proceedings Parallel Corpus 1996-2011. The aim was to extract any text that is affected to bilateral relations Hungarian/Romania-Slovakia, and to test automated translation of one selected sentence into 24 European languages by using Google translator. 


\begin{tabular}{|c|c|c|}
\hline - & 22.02 .2014 & europarl-vT.sk-en.en \\
\hline & 22.02 .2014 & Documents received: see Mlinutes \\
\hline & 22.02 .2014 & Written statements (Rule 116): see \\
\hline & 22.02 .2014 & Texts of agreements forwarded by \\
\hline & 22.02.2014 & Membershị of Parliament: see $\mathbf{M}$ \\
\hline & 22.02 .2014 & Membership of committees and de: \\
\hline & 22.02 .2014 & Future action in the field of patent \\
\hline & 22.02.2014 & Agenda for next sitting: see Minut \\
\hline & 22.02 .2014 & Closure of sitting \\
\hline & 22.02 .2014 & (The sitting was closed at 11.55 p.n \\
\hline
\end{tabular}

Record: $1281430 / 1281432$ Exclusive

Figure 8: Screenshot of BIKE - work environment with 1281430 sentences of the Corpus (English sentences)

\begin{tabular}{|c|}
\hline \\
\hline úradujúca predsedníčka Rady. - (SV) Vážený pán predsedajúci, právne predpisy túkajúce sa prístupu verejnosti k dokumentom, inými slovami to, co tu \\
\hline úradujúca predsednícka Rady. - (SV) Váženú pán predsedajúci, ako viete, väcsiu transparentnost považuje švédske predsedníctvo za nesmierne dôl \\
\hline úradujúca predsednícka Rady. - SV Váženú pán predsedajúci, švédske predsedníctvo venovalo mimoriadne vera času úsiliu o dosiahnutie ratifikáci \\
\hline úraduiúca predsednícka Rady. - (SV) Váženú pán predsedajúci, to, čo nazývame reštriktívnymi opatreniami, je vermi dôležité a viem, že mnohí poslanı \\
\hline úraduiúca predsednícka Rady. - (SV) Váženú pán predsedajúci, konflikt na Blízkom vúchode bol jednou z vecí, o ktorých sme tu v Parlamente diskutc \\
\hline úradujúca predsednícka Rady. Váženú pán predsedajúci, ešte raz vám đakujem za to, že ste predložli túto vermi dôležitú otázku. \\
\hline úradujúca predsednićka Rady. n nortová činnost v súčasnosti podlieha uplatñovaniu európskeho práva a ako pán poslanec správne uviedol, Lisab \\
\hline úradujúca predsednícka Rady. - Chápem problémy týkajúce sa situácie Írska, pretože je to ostrov závislý od prepravy. \\
\hline
\end{tabular}

Figure 9: Screenshot of BIKE - work environment with 1281430 sentences of the Corpus (Slovak sentences)

\begin{tabular}{|c|}
\hline Down Home =-> \\
\hline EUCorpus \\
\hline [1] \#ALL 1093 sentences \\
\hline [2] (::) Final query manuscript \\
\hline $\begin{array}{l}\text { [3] (SK) Madam President, al] } \\
\text { the new Member States, Slove } \\
\text { influenced by over-complexit } \\
\text { unclear rules and also hidden }\end{array}$ \\
\hline $\begin{array}{l}\text { [4] The countries were dividec } \\
\text { own country, Slovakia, unfort } \\
\text { unflattering place in only the t } \\
0.48 \% \text { of the original } 2 \% \text { it ha } \\
\text { science, education and researc }\end{array}$ \\
\hline
\end{tabular}

Figure 10: Screenshot of query obtaining by processing with BIKE - it was found 1093 appropriated sentences
[IUYL] We Slovaks have outlawed a similar radical orgamisation in our country.

[1093] A few months ago the Hungarian Prime Minister refused to meet his Slovak counterpart and ther [1094] Slovak-Hungarian relations have deteriorated recently.

[1095] On that occasion, the leader of the Hungarian Guard made some fairly shocking declarations, exr with Hungarian communities, that could attack Hungary.

[1] \#ALL 1093 sentences | Corpus | sk-en.prg | Extrakcia z 1.205 milióna viet do Slovak 1100 viet

Query z EU - parlament korpusu / Modul: Impact Factor

(SK) Madam President, allocations from EU funds in the new Member States, Slovakia incl bureaucracy, unclear rules and also hidden unfair interests.

The countries were divided into four groups, and my own country, Slovakia, unfortunate! investing just $0.48 \%$ of the original $2 \%$ it had committed to investing in science, education as I am pleased that I was present at the birth of this initiative, just like the two civic associati for Sundavr

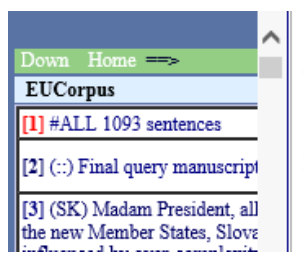

\section{European Parliament Proceedings Parallel Corpus 1996-2011}

For a detailed description of this corpus, please read:

Europarl: A Parallel Corpus for Statistical Machine Translation, Philipp Koehn, MT Summit 2005, pdf.

Please cite the paper, if you use this corpus in your work. See also the extended (but earlier) version of the report (ps, pdf).

Figure 11: Screenshot of browsing within the query in html - format 
EUCorpus [1] \#ALL 1093 sentences

[2] (:) Final query manuscrip1

[3] (SK) Madam President, al] the new Member States, Slove influenced by over-complexity unclear rules and also hidden 1

[4] The countries were divides own country, Slovakia, unfort unflattering place in only the $t$ $0.48 \%$ of the original $2 \%$ it ha science, education and researc [5] I am pleased that I was pre initiative, just like the two civ - the Large Families Club and

[6] I would ask you to look at

fallow in Poland, Lithuania an
[BASIC - Bi] |||||||||| English to Slovak |||||||||| Sk-Query: 1094 /1 250000 sentences (EU Corpus) $\Rightarrow$ As far as ...

EN $\Rightarrow 1$ !!! As far as states like Romania and Slovakia are concemed, the content of the constith situations

SK => 1 !!! :-) Č́o sa týka štátov ako sú Rumunsko a Slovensko, obsah takéhoto konštituovania môž ! aMT quality: :-) translated by Svetsky -- SEND TO: personal folder | cloud folder | MODUL:Impe

$\Rightarrow$ |||||||||| [EuroLangNet 21+3] |||||||||| English to => ES - PL - FR - DE - CZ ||||||||||

||||||||||

ES $\Rightarrow 1$ !!! Por lo que los estados como Rumania y Eslovaquia, el contenido de la constitució peligrosas ... aMTlink: http://www.systranet.com/translate/

aMT quality: L3Pulse // o key

$\||||||||| \mid$

PL $\Rightarrow>1$ !!! Tak daleko jak stany jak Rumunia i Sistani target6_0_zawartość konstytucja może tw

aMTlink http://www.systranet.com/translate/

Figure 12: Screenshot of template for automated translation into EU 24 languages via online translation services

\section{Conclusion}

In this paper, the overall approach and methodology of automation of teaching processes based on knowledge processing was presented. The practice of the participatory action research on technologyenhanced learning showed that it is not crucial whether the computer support is focused on a certain organizational form of teaching, or a field of Computer Science, because this resulted mostly to the indirect mono-purpose support or technology-specific solutions within state-of-the-art. For educational practice, it is more important to accept teaching processes as knowledge based, and the computer support understand as an issue of automation of these processes where the knowledge is a basic parameter of the process. In this content, the paper has presented basic pillars of automation of teaching processes developed within the research on TEL, especially (i) an universal knowledge representation in the form of virtual knowledge unit (as the knowledge abstraction of real world), and (ii) in-house developed software BIKE (it runs only on the author's computer) / WPad (a standalone platform for knowledge processing and exchange on desktop computers or clouds), for performing (iii) the batch knowledge processing paradigm, which enables individuals to process "big" educational data. The paper further emphasized a need of modification and unification of teaching content and processes, in parallel with informatics processes running on computers in order to create applications, which are needed for supporting a set of teacher's job activities and processes. This was illustrated on the several examples of applications implemented in engineering teaching bachelor's students. Because the described approach resulted into a vision of "human centered computer intelligence", the actual research activities are focused as well on the modelling creativity support of individuals (solutions when writing English papers, text of songs, or multilingual issues in the field of Human Technology Languages-e.g. a PanEULangNetproject was proposed in the ICT 17 call of Horizon 2020 in this year).

\section{ACKNOWLEDGEMENT}

This work was supported within the funded project KEGA No. 047STU-4/2012: The building online teaching room for education in the field of machining of complex shaped components. 


\section{REFERENCES}

[1]. TeLearn-European research on technology-enhanced learning. http://cordis.europa.eu/fp7/ict/telearndigicult/telearn_en.html

[2]. Svetsky, S, et al., The Educational - Driven Approach for Technology Enhanced Learning. World Congress on Engineering and Computer Science on, 2012. Proceedings IAENG \& IET: p. 290-296.

[3]. Svetsky, S. The practical aspect of knowledge construction and automation of teaching processes within technology-enhanced learning and eLearning. Habilitation thesis. Slovak University of Technology; 2012.

[4]. Svetsky, S. et al. The Particular Approach for Personalised Knowledge Processing. In: Advances in Intelligent and Soft Computing. Springer-Verlag Berlin Heidelberg, 2012, pp. 937-946.

[5]. S. Svetsky - O. Moravcik: The practice of Research on Technology - enhanced Learning. In: International Journal of Computer and Information Technology. Vol. 2, Iss. 4 (2013), s. 701-705.

[6]. Goodman Paul S., et al. Technology Enhanced Learning: Opportunities for Change. Laurence Erlbaum Associates, Mahwah, NJ, USA; 2002.

[7]. Skalková, J. The general Didactics (Obecná didaktika). Grada Publishing. a.s. 2007 (ISBN 978-80-247-1821-7)

[8]. Cube, F. v.: Die kybernetische - informationstheoretishe Didaktik. Westermanns Pädagogishe Beiträge, 32, 1980 , č. 3, s. 120-124.

[9]. Saljö, R. Digital tools and challenges to institutional traditions of learning: technologies, social memory and the performative nature of learning. Journal of Computer Assisted Learning. Vol.26, pp. 53-64; 2010.

[10]. N. Balacheff, S. Ludvigsen, T. Jong, A. Lazonder, S. Barnes (Eds.). Technology - Enhanced Learning. Principles and Products. Springer, 2009, XXVI, 326 p.

[11]. R. Sutherland, S. Eagle, M. Joubert. A Vision and Strategy for Technology Enhanced Learning:Report from the STELLAR Network of Excellence. STELLAR, 2012. [cit. 2014-07-15] Available at http://www.teleurope.eu/pg/file/read/152343/a-vision-and-strategy-for-technology-enhanced-learningreport-from-the-stellar-network-of-excellence.

[12]. C. L. P. Nápoles, L., Montandon (Eds). D 1.1.2 Emerging technologies landscape: Report on Field Research results. Public report final 7-30/4/2013-M7 audience. HoTEL, 2013. [cit. 2014-07-15] Available at http://hotel-project.eu/content/d112-emerging-technologies-landscape-report.

[13]. A. Stolar. META-EDUCATION. Journal of Technology and Information Education. 2009, Olomouc - EU, Univerzita Palackého, Ročník 1, Číslo 1, s. 7-18.

[14]. P. Dillenbourg, Integrating technologies into educational ecosystems. Distance Education, Routledge - Taylor \& Francis Group (2008), Vol. 29, No. 2, p.127-134.

[15]. Derry, J. Technology - Enhanced Learning: A Question of Knowledge. Journal of Philosophy of Education, vol. 42, pp. 505-519; 2008. 
[16]. D. Laurillard, "Technology Enhanced Learning as a Tool for Pedagogical Innovation," Journal of Philosophy of Education, vol. 42: pp. 521-533, 2008.

[17]. Kinchin, I. (2012). Avoiding technology-enhanced non-learning. British Journal of Educational Technology, 43(2), E43-E48.

[18]. Crispin Weston. The problem with "Technology Enhanced Learning", http://edtechnow.net/2012/12/05/tel/, Ed Tech Now, 2012.

[19]. University of Oxford. SSD/MT10/MScEd, http://www.ox.ac.uk/media/global/wwwoxacuk/localsites/gazette/documents/examregs/oldsocsci/13-0111_MSc_in_Education.pdf

[20]. Nielsson. J.N., Human - Level Artificial Intelligence? Be serious! Al Magazine 25 anniversary Issue. Winter 2005, p. $68-75$. 